Saral Güneș, S., Kükrer Aydın, Ö. / Journal of Yasar University, 2016, 11/43, 220-239

\title{
Tüketim Kültürü Çerçevesinde Lüks Yaşam Tarzlarının Dekorasyon Dergilerindeki Reklamlarda Sunumu: Home Art Dekorasyon Dergisi Örneği
}

\section{The Presenation of Luxury Lifestyles on Decoration Magazine Advertisements within the Frame of Consumption Culture: Example of Home Art Decoration Magazine}

Selda SARAL GÜNEŞ, Akdeniz Üniversitesi, Türkiye, seldasaral@akdeniz.edu.tr

Özlem KÜKRER AYDIN, Akdeniz Üniversitesi, Türkiye, okukrer@akdeniz.edu.tr

\begin{abstract}
Özet: Kapitalizmin varlığını sürdürebilmesinin ön koşulu olan tüketim toplumunun yaratılmasl, reklamlar araclliğı ile dayatılan sembolik ihtiyaçlar ve sunulan yaşam tarzları neticesinde gerçekleşmektedir. Reklamdaki anlamın nasıl tasarlandığı ve sunulduğu ise kullanılan göstergelerin analizi ile anlaşılmaktadır. Bu çerçevede çalışmanın amacı, dekorasyon dergilerindeki reklamlar aracllığlyla tüketim kültürü çerçevesinde lüks yaşam tarzlarının nasıl sunulduğunu ve tüketim ideolojisinin nasıl yeniden üretildiğini ortaya koymaktır. Bu amaçla, konutların ve konut dekorasyonlarının önemli bir yaşam tarzı göstergesi haline geldiği savindan hareketle, Türkiye'nin en çok okunan dekorasyon dergilerinden biri olan Home Art'ın, Mayıs 2015 sayısı içerisinden, çalıșmanın amaçları doğrultusunda yargısal olarak seçilen

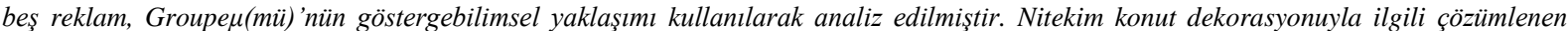
reklamlarda, doğallık, nostalji (Osmanlı ve saray metaforları), eğlence, estetikleştirilmiş yaşam, ikilik ve çeşitlilik (yeni-eski, doğu-batı, klasikmodern, doğal-yapay, sanatsal-teknolojik) gibi postmodern tüketim toplumuna ait nitelikler aractlı̆̆ıla lüks yaşam tarzlarının yeniden üretildiği ve insanların bu yaşam tarzlarına öykündürüldüğü görülmektedir.
\end{abstract}

Anahtar Kelimeler: Reklam, Tüketim, Yaşam Tarzl, Göstergebilim, Groupe $\mu(m u ̈)$.

\begin{abstract}
The creation of consumption society, that is the precondition for the presence of capitalism takes place as a consequence of symbolic needs and luxury lifestyles by advertisements. Besides, how to design and present the meaning of advertisements can be understood by the analysis of the indicators. In this context, the aim of the study is demonstration of the how luxury lifestyles are presented and the ideology of consumption is reproduced through advertisements within the frame of consumption culture. For this purpose, in the light of residences and decoration of residences are becoming the important lifestyle indicator, data was gathered from five advertisements using the judgmental sampling method. The sample advertisements is in Home Art which is one of the most popular decoration magazine in Turkey press on May 2015, are analysed by using Groupe $\mu(m \ddot{u})$ 's semiological approach. The main results of the analysis are that the luxury lifestyles are reproduced and people emulate the luxury lifestyles by qualifications of postmodern consumption society such as naturalness, the nostalgia (the methaphors of Ottoman and palace), entartainment, aestheticized of life, duality and diversity (new-old, east-west, classic-modern, natural-artificial, art-technology) on advertisements.
\end{abstract}

Keywords: Advertisement, Consumption, Lifestyle, Semiotic, Groupe $\mu$ (mü).

\section{Giriş}

Gündelik yaşantımızı kuşatmış olan reklamlar, bir taraftan bireyleri ürünleri ya da hizmetleri satın almaya yönlendirerek kapitalizmin ekonomik yeniden üretimine hizmet ederken, bir taraftan da sahip oldukları içerikler ile kapitalizmin toplumsal yeniden üretimine hizmet etmektedir (Dağtaş, 2009, 19). Yalnızca ürün ve hizmet tanıtımlarının ötesinde bir tüketim kültürü yaratma çabasında olan reklamlar, özellikle Türkiye açısından 
bakıldığında, 1980'lerde Türkiye'de uygulanmaya başlanan neo-liberal politikalar ile bugünkü tüketim kültürüne zemin hazırlayarak kültürel yapıyı önemli ölçüde dönüştürmüştür. Bunun sonucu olarak insanlar, medya aracılığı ile belirlenen yüksek statü göstergelerini ortaya koymak ve bunu meşrulaştırmak için diğer insanlara ve sınıflara karşı mücadele eder hale gelmişlerdir (Korkmaz, 2009, 149-152). Birey bu mücadelesini, giyiminden, kullandığ1 otomobile, tatilinden, satın aldığı konuta kadar her alanda sürdürmektedir.

Reklamdaki göstergeler aracılığı ile yaratılan tüketim toplumu (Baudrillard, 2010), sosyal statülerin tüketilen ürünler üzerinden belirlendiği bir oluşum yaratmış; artık bireyin, satın aldığı ürün ile toplumsal statüsünün belirlendiği bir noktaya ulaşılmıştır (Williamson, 2001, 13). Özetle küresel kapitalizmin ideolojisi doğrultusunda yaratılan tüketim kültürü ile tüketim, bir ihtiyacı karşılamaktan öte statü, prestij, sınıf atlama, kimlik edinme, bir gruba ait olma gibi simgesel değerler adına yapılır hale gelmiştir (Dağtaş, 2003, 77). Nitekim bu durum reklamlarda sunulan vaatlerde de oldukça belirgin bir şekilde görülmektedir.

Tüketim kültürünün zemin oluşturduğu kültürel dönüşümle birlikte, bireyselciliğin arttığı ve toplumsal olanın gündem dışı bırakıldığı bir yaşam tarzı ortaya çıkmıştır (Aydoğan, 2009, 211). Medya bu yaşam tarzının sunumunda başat rol oynamıştır. Günümüzde de medyada, hangi mekanlarda yenilip içileceği, nelerin giyileceği, hangi sporların yapılacağı, tatil için nerelerin tercih edileceği, hangi müzik türünün dinleneceği gibi insanın tüm yaşamını kuşatan hazır bir yaşam tarzı sunulmaktadır. Bu yaşam tarzlarının sunumunda kullanılan göstergeler incelendiğinde konutların ve konut dekorasyonlarının önemli bir yaşam tarzı göstergesi haline geldiği gözlemlenmektedir. Bir diğer ifade ile 1980 sonrası kentsel mekanlar, sermayenin bağlılığına ve verimliliğine paralel olarak tüketime dayanan yaşam tarzlarına göre yeniden şekillendirilmiş; artık mekanlar sınıflar açısından ayrışmanın bir göstergesi haline gelmiştir (Bocock, 2014). Yaşam tarzının, ekonomik ve kültürel sınıfsal ayrışmanın en önemli göstergelerinden biri olması mekanları bu ayrışmada oldukça etkili kılan nedenler arasindadir.

$\mathrm{Bu}$ çalışmada konutların ve konut dekorasyonlarının önemli bir yaşam tarzı göstergesi haline geldiği savından haraketle, Türkiye'nin en çok okunan dekorasyon dergilerinden biri olan Home Art'1n, Mayıs 2015 sayısı içinde yer alan beş reklam çalışmanın amaçları doğrultusunda yargısal olarak seçilmiş ve seçilen reklamlar Groupe $\mu$ (mü)'nün göstergebilimsel yaklaşımı kullanılarak çözümlenmiştir.

\section{Kapitalizm, Üretim ve Tüketim İlişkisi}

Kapitalizm, bireyleri iş dışındaki zamanlarında tüketime yönlendiren bir üretim ve tüketim modelidir. Bu doğrultuda kapitalizmin hakim ekonomik sistem olduğu toplumlarda, tüketim bir yaşam tarzı haline gelmiştir. Temel sorunu üretim değil; aksine ihtiyaç fazlası üretimin tüketilmesi olan kapitalizm, egemen sistem olarak tüketimin yalnızca ihtiyaçlar doğrultusunda yapıldığı ortamda varlığını sürdüremeyecek ve krize girecektir. Doğası gereği krizlere uygun olan kapitalizmin, 1929 ekonomik buhranı ve 1970’lerde yaşadığı krizler üretilen malların tüketiminin sağlanamadığı örneklerden bazılarıdır (Galbraith, 2009; Işık ve Duman, 2012).

Üretim ve tüketim süreçlerinde yaşadığı krizler ile kapitalizm, endüstriyel yaşamın örgütlenmesi açısından 1950-70 ve 1970’ten sonrası olmak üzere Fordizm ve postfordizm olarak adlandırılan iki döneme ayrılmaktadır. Henry Ford tarafından geliştirilen ve kapitalist üretim şeklini tanımlamak için kullanılan Fordizm (Dağtaş, 2009, 25), ürünlerin standartlaştırıldığı ve seri üretimin yapıldığı bir üretim şeklidir. Aynı maldan çok sayıda üretilen fordist üretim şeklinde bu üretime paralel olarak tüketimin de gerçekleşmesi gerekmektedir. Bu amaç doğrultusunda Fordizm, seri üretime paralel olarak kitlesel tüketimi amaçlamaktadır. Esas hedef kitlesi 
işçiler olan bu sistemde, işçilerin birer tüketiciye dönüştürülmesinde ve kitlesel tüketimin yaratılmasında genelde kitle iletişim araçları özelde ise reklamcılık sektörü etkin rol oynamıştır.

Fordist sistemde reklamlar ile amaçlanan, bir taraftan fazla üretimin tüketilmesiyken bir taraftan da tüketimin sürekliliğinin sağlanmasıdır. Psikolojik tatminler ve bilinç altına hitap eden içeriklerin hakim olduğu fordist dönemin reklamlarında, bireylerin ürünle kurdukları ilişki sonucunda yaşayacağı duygular işlenmiş ve ürüne sahip olmanın sağlayacağı gurur ve sahip olmamanın vereceği endişe tüketiciye aşılanmaya çalışılmıştır (Leiss vd. 1990, 246-259'dan aktaran Dağtaş, 2009, 27). 1970'lere gelindiğinde ise kitlesel üretim ve kitlesel tüketim sistemi olan Fordizm bir tıkanma yaşamış ve sistem krize sürüklenmiştir.

Kitlesel olarak üretilen ürünlerin artık satılmıyor olması, yeni üretim şekilleri ile daha az sayıda ama daha çok çeşitte ürünün üretilmesi şeklinde yeni bir sistemi doğurmuştur. Postfordizm olarak adlandırılan bu sistem ile ağır sanayi zayıflamış ve gelişen hizmet sektörü ile birlikte yeni bir orta sınıfın doğmasına zemin hazırlanmıştır (Featherstone, 2005). Ekonominin büyümesi ve küreselleşme sonucu ortaya çıkan kentli, yeni orta sınıf, yüksek eğitim standartlarına, uzmanlığa ve sermayeye erişimleri aracılığıyla, zenginliğe ve dolayısıyla yüksek satın alma gücüne sahiptir.

Değişen üretim yaklaşımına ve tüketici sınıfına paralel olarak yeni bir tüketim anlayışı da kaçınılmaz olarak ortaya çıkmıştır. Postfordist sistem içerisinde yalnızca ekonomik değil aynı zamanda toplumsal ve kültürel bir süreç olan tüketim, maddi gereksinimlerin doyurulmasından öte, sembollerin oyunu ile yönetilen bir süreç olarak görülmektedir. Bu dönemde tüketiciler maddi gereksinimlerinden çok gösterge ve sembollerin tüketimiyle duygusal arzularını doyurmaya çalışmaktadır (Baudrillard, 2010, 72). Bugün "ben kimim" sorusunun cevabında meslek rolü kadar, tüketim kalıplarının da belirleyici olması bunun göstergesidir. Artık tüketim, "postmodern" kapitalizmin tipik özelliklerini sergileyen bir süreç haline gelmiştir (Bocock, 2014, 113).

Postmodern tüketimin en belirgin özelliklerinden biri, tüketimin arzu ve haz odaklı gerçekleştirilmesidir. Haz odaklı bir diğer deyişle hedonik tüketim, tüketim sürecinde metaların kullanım değerlerinin dışında, tüketimin duyusal, duygusal ve fantazi boyutlarını kapsamaktadır (Hirschman ve Holbrook, 1982, 100). En temel ifade ile hedonik tüketim duygusal tatmine odaklanan tüketim şeklidir. Hedonik tüketimde, tüketim ve kimlik oluşturma süreci arasında bir bağ kurulmuş ve tüketim, ihtiyaçlar doğrultusunda yapılan bir eylem olmaktan çıkmış; haz veren bir boş zaman aktivitesi haline dönüşmüştür.

Hedonik tüketimin en belirgin özelliği ise bireylerin tatmin sağlamak için sürekli olarak bir tüketim arayışı içerisinde olmalarıdır. Bauman $(1997,34)$ 'a göre bireyler varolan sistemde hayatta kalmak için tüketim piyasası tarafından teşvik edilen sayısız olasılık içinde, sürekli yenilenme sürecine kapılarak kimlik edinme ve bu kimlikleri terk etme şansından haz almalı ve gittikçe yoğunlaşan duyguları ve deneyimleri sürekli olarak takip etmelidir. Varolan ekonomik sistemin ve tüketim kültürünün devamlıllğı ancak bu kısır döngü aracıllğıyla gerçekleşmektedir.

Sonuç olarak modern ve postmodern dönemlere hakim olan farklı üretim, tüketim biçimleri toplumsal ve kültürel dönüşümü de beraberinde getirmiştir. Tüm bu gelişmeler etrafinda 19. yüzyılın sonlarından başlanarak bugünkü tüketim kültürünün temelleri atılmıştır. Bu dönüşümler tüketim odaklı farklı yaşam tarzlarının doğmasına yol açmıştır. Günümüzde özellikle reklamlar ile tüketim kültürü içinde var olan gösteriş̧̧i yaşam tarzlarının yeniden üretildiği görülmektedir. 


\section{Tüketim Kültürü, Reklam ve Yaşam Tarzı}

Kapitalizmin temel amacı, var olan aşırı üretimin tüketilmesini sağlarken, tüketimin kalıcı hale gelebilmesi için onu bir kültür olarak benimsetmektir (Dağtaş ve Dağtaş, 2009, 51). Bu çerçevede en temel ifade ile tüketimi ve haz odaklı yaşamı merkeze alan bir kültür olan tüketim kültürü ortaya konulmuştur. Tüketim kültürü, öncelikle maddi ürünlerin yalnızca fayda odaklı değil; aynı zamanda iletişim vasıtası olarak kullanılması ile iktisadın kültürel boyutuna; ikinci olarak da yaşam tarzları, kültürel ürünler ve metalar alanı içerisinde işleyen piyasa ilkelerine odaklanmaktadır (Featherstone, 2005, 142-143). Bir başka deyişle, tüketim kültürü içinde tüketimin sağladığı iktisadi faydadan çok, yaratılan kültürel ve toplumsal değişimlerin üzerinde durulmaktadır. Bu durum, tüketimin ihtiyaç odaklı, işlevsel bir eylem olmaktan ziyade sembolik amaçlarla gerçekleştirilmesine zemin hazırlamaktadir.

Tüketim kültüründe benzer niteliklere sahip olduğu ve tektipleştiği için tüketiciler nezdinde değer kaybeden metalara yeni anlamlar yüklenmektedir. Bu nedenle tüketim kültüründe malların işlevselliğinden çok yaratılan gösterge değerleri önemlidir (Baudrillad, 2010). Bu doğrultuda artık malların kendisi değil; sahip oldukları anlamlar bireylerin arzularını tatmin etmeye yönelik tüketilmektedir. Ancak bireyler "hayatlarını üsluplaştırarak" (Featherstone, 2005, 145) diğer tüketicilerden farklılaşmak için sürekli olarak yeni tüketim nesnelerine arzu duymaktadır. Kimlikleri tüketim üzerine kurulu olan insanlar, bu ürünleri satın alamayacaklarında dahi ona sahip olmak için çalışmaktadır. Bireyin tüketimi gerçekleştirdiği anda yaşadığı anlık tatmin ise kısa bir süre sonra yerini yeni tüketim ihtiyacına bırakmaktadır. Sonu gelmeyen bu tüketimin asıl nedeni, bir metaya duyulan ihtiyaç değil, farklılaşma arzusudur (Dağtaş ve Dağtaş, 2009, 69-70). Bu nedenle sınıfsal ayrışmanın, sahip olunan maddi ve kültürel imkanlara dayanan tüketim kalıpları ile gerçekleştiği tüketim toplumunda, tüketebilme arzusuyla çalışan insan, kendisinin olmasa bile bir gün çocuğunun hatta torununun tüketebilmesi ümidiyle yaşamaktadır (Korkmaz, 2009, 161-162). Bu gerekçelerle tüketimi bir amaç haline getiren bireyler için işlevsel olarak neyi, ne amaçla tükettiğinin önemi yoktur. Bu bağlamda tüketim kültürü içinde gerekli gibi görünen birçok harcama aslında bireyin saygınlığını koruyabilmesi için yaptığı israf niteliğinde olan harcamalardır.

Featherstone $(2005,49)$, israfın kapitalist toplumlarda denetlenmesi ve yönlendirilmesi gereken bir edim olduğunu belirtmektedir. Ancak bu sistem içerisinde bireyin tüketim alışkanlıklarını azaltması, birey için daha çok çalışıp daha çok tüketme çabasından çok daha zordur. Tüketici içinde bulunduğu sürecin farkında olsa da, bir süre sonra hayatının bir parçası olan tüketimden, zaten düşük olan hayat standardını daha da düşürmek korkusuyla asla vazgeçemez hale gelmiştir (Veblen, 2014, 82-83).

Tüketimin sürdürülmesi ve oluşturulan tüketim kültürünün aktarımında en temel araç genelde medya iken özelde reklamlardır. Reklam, tüketim kültürünün ve bu kültür içerisinde ortaya çıkan yaşam tarzlarının bireylere sunulmasında en önemli araçlardan biridir. Reklamlar aracılığıyla insanlara satın aldıkları ürünler ile sınıf atlayacakları vaat edilerek sınıf farklılıklarının üzeri örtülmektedir. Söz gelimi, bir işçi, satın aldığı akıllı telefon sonucunda artık ait olduğu işçi sınıfından kurtulduğu şeklinde bir yanlış bilince kapılmaktadır (Williamson, 2001,13). Bu gerekçelerle reklamlarda, bir ürünün tanıtımından öte onunla elde edilecek simgesel değerlerin sunulduğu görülmektedir. Örneğin, bir otomobil reklamında motorun gücü ve yakıt tüketimi gibi ürün özelliklerinin vurgulanmasından ziyade, bireylere bu otomobil ile sahip olacakları statü, sosyal sınıf gibi sembolik faydalar vaat edilmektedir. 
Günümüz reklamlarında bireylere tüketim aracılığıyla yüksek statü gibi nitelikler vaat edilirken tüketim toplumunun çeşitli nitelikleri vurgulanmaktadır. Reklamlarda "günlük hayatın estetikleştirilmesi" en sık kullanılan tüketim kültürü niteliklerindendir. Bu nitelik reklamlarda vurgulanırken sanata dair unsurlar değişime uğratılarak reklamlarda yer almaktadır. Bu doğrultuda "estetik, işlevsel olma ve teknoloji sanatla buluştu" tarzındaki sloganlarla bezenmiş reklamlar çoğalmaktadır (Akçalı ve Yücebaş, 2013; Odabaşı, 2006). Özellikle otomobil, beyaz eşya, cep telefonu gibi ileri teknoloji gerektiren ürünlerin reklamları aracılığıyla rakiplerinden farklılaşmak ve tercih edilebilirliklerini arttırmak için teknolojik niteliklerinin estetik unsurlara vurgu yapılarak aktarıldı̆̆ sıklıkla görülmektedir. Reklamlarda yoğun olarak görülen diğer nitelikler ise ürünü deneyimlemenin eğlence-oyun haline gelmesi (Baudrillard, 2010, 93; Odabaş1, 2006, 157,) doğaya dönüş (Williamson, 2001, 126), zıtlıkların birlikteliği (doğa-teknoloji birlikteliği gibi), yerellik ve geçmişin (nostaljik unsurların) (Odabaş1, 2006, 170) vurgulanmasıdır. Özetle, postmodern toplumda tektipleşen ürünleri farklılaştırmak için reklamlar, ürünlerin işlevsel özellikleri hakkında çok az bilgi sunmakta; ürünleri tüketim kültürünün toplumsal yapısını destekleyecek sembolik niteliklerle bağlantılandırılmaktadır.

Değişen üretim sistemlerine bağlı olarak toplumsal yapılarda görülen dönüşümlerin reklamlara yansımasının bir sonucu olarak farklı dönemlerde farklı reklam formatları kullanılmıştır. İlk dönem olan endüstriyel kapitalizm döneminde (1880-1925), ürün-bilgi formatının hakim olduğu reklamlar kullanılmıştır. Üreticiler arasında rekabetin neredeyse olmadığı bu dönemin reklamlarında ürünün işlevi, fiyatı, fiziksel faydaları üzerinde durulmuştur. İkinci dönemde (1925-1945) ise ürün-imaj formatı kullanılmıştır. Bu dönemde rekabetin ortaya çıkmasına paralel olarak pazara benzer ürünlerin sunulmaya başlanması ile reklam metinlerinde rasyonellikten uzaklaşıldığı ve ürünü satmak için statü, mutluluk gibi sembollerin ve marka imajının kullanılmaya başlandığı görülmektedir. Üçüncü dönemde (1945-1965) ise kişiselleştirme formatı kullanılan reklamlarda, insan kişiliği ve buna bağlı olarak psikolojik kavramlar ön plana çıkarılmış olup; bireylerin ürünleri kullanımları sonrası yaşayacağı gurur, mutluluk, doyum gibi duygular işlenmiştir. 1965'lerden günümüze kadar gelen dönemde ise reklamlara yaşam tarzı formatı hakimdir. Bu dönemde, reklam metinlerinde yaşam tarzı sunumu ön plandadır. Ürün ile belli bir yaşam tarzı arasında bağlantı kurulan bu dönemin reklamlarında, ürünün toplumsal anlamı ön plana çıkartılmaktadır (Leiss vd., 1990, 153-169'dan aktaran Dağtaş, 2009, 43-45). Nitekim bu dönemde artık ürünün rasyonel faydası göz ardı edilerek tüketim süreci, satın alınan ürünün yaşam tarzı üzerindeki etkisine indirgenmiştir.

Reklamcılık içinde bulunduğu ekonomik ve toplumsal koşullardan etkilenerek farklı dönemlerde, farklı toplumsal ve kültürel değerler ile varolan sistemin devamlılığını sağlamaktadır. Bu doğrultuda tüketim kültürünün yaşam tarzının dönüşümüne odaklanmasının bir sonucu olarak reklamlarda da kaçınılmaz olarak ürünler ve yaşam tarzları arasında bağlantı kurulduğu gözlemlenmektedir. Kapitalist sistemin temelinde yatan değerleri, göstergeler aracılığı ile yeniden üreterek meşrulaştıran reklam, bireylerin yaşam tarzlarını tüketim üzerine odaklamaktadır. Günümüz medyası da adeta paketleyerek sunduğu yaşam tarzlarını ticari birer meta haline getirmiştir (Dağtaş ve Dağtaş, 2009, 9). Bu doğrultuda bireyler statü, saygınlık kazanma ve haz odaklı yaşama gibi ideallerine ulaşmak için yaşamlarını medya aracılığıyla sunulan yeni ve farklı yaşam tarzına göre biçimlendirme çabası içine girmektedir. Bireyler, tüketim kültürü içerisinde yeniden yapılandırılan yeni yaşam tarzlarına ulaşmak için de özellikle reklamlar ile sunulan ürünlere ulaşmaya çalışmaktadır.

Günümüzde yaşam tarzı, tüketim kültürü içerisinde belirli farklı sınıflar için belirli zevkler doğrultusunda oluşan tüketim kalıplarıdır. Tüketim kültüründe bireyler yaşam tarzlarını adeta birer proje gibi yöneterek, bu 
projeler kapsamında yaşam tarzlarını yalnızca dış görünüşleri ile değil; konuşmaları, boş zaman aktiviteleri, yemek zevkleri, evleri ve arabaları ile oluşturmaktadır (Featherson, 2005, 145). 1980'li yılların ortasından itibaren medyada yaygın olarak "lifestyle" ifadesiyle kullanılan yaşam biçimi, lüks konutlarda yaşamanın yanı sıra, kaliteli lokantalarda yemek yeme, en iyi şarapları içme, giyim kuşama özen gösterme, boş zamanlarını tablo, nadir kitap ya da klasik araba koleksiyonu yaparak geçirme gibi süzülmüş zevklerden oluşan bir bütündür (Bali, 2007, 146). Artık bireyin ait olmak istediği sınıf ve sahip olmak istediği yaşam tarzı için sıradan tüketim kalıplarının dışına çıkmaktan ve tüketimlerini arzu ettiği yaşam tarzları doğrultusunda biçimlendirmekten başka çaresi bulunmamaktadır.

Yaşam tarzının önemli göstergelerinden biri de tüketicilerin konut alanlarıdır. Türkiye gibi gelişmekte olan ülkelerdeki kentlerin daha heterojen olma eğilimi ile konut alanlarındaki ayrışma hız kazanmaktadır. Bir tarafta kent nüfusunun büyük bir bölümü, mülkiyet güvencesi açısından belirsiz, ruhsatsız, kamu hizmetlerinin yetersiz kaldığı bölgelerde yaşamaya devam ederken; diğer tarafta ise orta ve üst sinıflar, tam donanımlı, tecrit edilmiş semtlerde yaşamlarını sürdürmektedir. Maddi durumu iyi olan orta sınıf aileler, kendilerinden daha alt sınıfa mensup insanlardan iyice ayrışmak için kent dışındaki uydu kentlere taşınmaktadır. Temel sosyal etkinliği alışveriş olan bu uydu kentlerdeki orta sınıf kimliği, çoğunlukla tüketim çerçevesinde ortaya konulmaktadır (Ayata, 2012, 37-38). Bir başka deyişle, bu yeni orta sınıf bulundukları yerleşim bölgesi, konut tipi, konutun fiziki çevresi ve konut mülkiyeti güvencesi gibi gerekçelerle tercih ettikleri konutlarının yanı sıra yaşam tarzlarını destekleyecek çeşitli tüketim tercihleri yapmak durumundadır.

Konut bölgelerindeki ayrışmanın yanı sıra konutların iç dekorasyonları da bireylerin yaşam tarzlarını yansıtan önemli göstergelerdir. Günümüzde bireyler için mekan "...zamandışı ve hiçbir çıkar gözetmeyen, bir güzelliğin kendi içinde bir amaç olarak elde edilmesi amacı hariç, estetik hedef ve ilkelere göre biçimlendirilen bağımsız ve özerk bir şeydir." (Harvey, 2010, 84). Bu nedenle kişiler zevkleri ve estetik tercihleri doğrultusunda en önemli yaşam tarzı göstergelerinden biri olan konutlarını ve konutlarının dekorasyonlarını dikkatle belirlemektedir. Tüm bunların bir sonucu olarak reklamlarda da çok katlı apartman ya da villalardan oluşan ve içerisinde alışveriş merkezinden parkına, yüzme havuzundan okuluna her türlü tüketim imkanı sunan yaşam alanları (Korkmaz, 2009, 154) ve yaşam alanlarının tasarlanmasına ilişkin göstergeler sıklıkla kullanılmaktadır.

\section{Yöntem}

$\mathrm{Bu}$ çalışmanın amacı, dekorasyon dergisindeki mobilya reklamları aracılığıyla lüks yaşam tarzlarının nasıl sunulduğunu ve tüketim ideolojisinin nasıl yeniden üretildiğini ortaya koymaktır. Makalenin amacına uygun olarak, Türkiye'nin en çok okunan dekorasyon dergilerinden biri olan Home Art, Mayıs 2015 sayısı içindeki mobilya reklamları örneklem olarak seçilmiştir. Derginin Mayıs 2015 sayısı 274 sayfadır. 274 sayfa içerisinde 90 reklam yer almaktadır. Bu reklamların 50 tanesi mobilya ve diğer dekorasyon ürünleri kategorisindedir. Örneklem belirlenirken, mobilya ve dekorasyon kategorisindeki 50 reklamın yüzde 10'u, çalışmanın amaçları doğrultusunda yargısal olarak belirlenmiştir. Araştırmada Home Art dergisinin tek sayısındaki reklamlar analiz edilmiştir. Reklamlar analiz edilirken nitel bir araştırma tekniği kullanıldığı için analiz sonuçları, tüm evrene genellenme kaygısı taşımamaktadır. Bu doğrultuda araştırmanın sınırlılığı, Home Art dergisinin Mayıs 2015 sayısındaki yargısal örneklemle belirlenen reklamların analiz edilmesidir.

Derginin Mayıs 2015 sayısında yayınlanan ve çalışmanın amaçları doğrultusunda yargısal olarak seçilen beş reklam Groupe $\mu(m u ̈)$ 'nün göstergebilimsel yaklaşımı kullanılarak analiz edilmiştir. Groupe $\mu$ (mü)'nün 
göstergebilimsel yaklaşımı çerçevesinde gerçekleştirilen analizlerde, reklamlardaki renk, biçim, doku, kompozisyon gibi plastik göstergeler ve gerçek hayattaki varlıklarla benzerlik gösteren ikonik göstergeler, iki ayrı gösterge sınıfı olarak ele alınmış ve reklamın tüketicileri görsel yol ile ikna süreçleri incelenmiştir.

Avrupalı dilbilimci Ferdinand de Saussure'ün, Cenevre Üniversitesi’nde verdiği derslerin notlarından derlenerek ölümünden sonra 1916'da yayınlanan 'Genel Dilbilim Dersleri' ile ilk kez dile getirilerek temellerini atan (Barthes, 2014, 27) ve 1960'lı yıllarda Amerikalı, mantıkçı ve matematikçi C. S. Peirce ile bağımsız bir bilim haline gelen göstergebilim, her çeşit bilimsel inceleme için bir başvuru çerçevesi oluşturan genel bir kuramdır (Rıfat, 2005,116). Groupe $\mu$ (mü), yapısal yönteme dayalı yeni bir görsel dizgeselleştirilme geliştirerek, görsel göstergebilimde ikonik içerik düzlemi ve plastik anlatım düzeyi temel ayrımını benimsemiş̧ir (Yücel, 2013, 92).

Groupe $\mu$ (mü) Belçika'da, Liege Üniversitesi Şiirsel Araştırmalar Merkezi’nde 1967'den bu yana, retorik, şiir, göstergebilim, dilbilimsel ve görsel iletişim kuralları üzerine çalışmalar yapan bir gruptur. Francis Edeline, Jean-Marie Kilinkenberg, Jacques Dubois, Francis Pire, Hadelin Trinon ve Philippe Minquet günümüzde de halen çalışmalarına devam eden grup üyeleridir. Oldukça farklı alanlardan gelen bu araştırmacılar ile Groupe $\mu$ (mü)'nün en önemli özelliklerinden biri çok disiplinli olmasıdır (İnceoğlu ve Çomak, 2009, 289). İlk kurulduğu yıllardan itibaren görsel iletişim konusunda eğilen Groupe $\mu($ mü) üyelerinden Francis Edeline, Jean-Marie Kilinkenberg, Philippe Minquet tarafından yazılan Görsel Göstergelerin Kitabl, görsel göstergebilim konusundaki en önemli kuramsal yapitlardan biridir (İnceoğlu ve Çomak, 2009, 292).

\subsection{Plastik Göstergeler}

Groupe $\mu$ (mü)'nün geliştirerek kendisine özerklik verdiği plastik göstergeler, ikonik göstergelere bağımlı ve onunla birlikte var olabilmelerine karşın, ikonik göstergelerin bir parçası değil, tek başına bir göstergedir. Umberto Eco, plastik göstergelerin tüm imgeler için değiş̧mez bir değer ifade etmediğini çünkü plastik göstergelerin öğeler arasındaki bağlantı ile anlam kazandığını savunmaktadır (Yücel, 2013, 97-98). Groupe $\mu$ (mü) renkler, biçimler ve dokular şeklinde ayrılan plastik gösterge ailelerinin işlevlerini aşağıdaki gibi açıklamaktadır (İnceoğlu ve Çomak, 2009, 294-297).

\subsubsection{Renkler}

Groupe $\mu$ (mü) renklerin sıcak/soğuk ve kontrastlar olarak bölümlenebileceğini belirtmektedir. Işık, karşıtlık, benzerlik gibi kavramların yardımı ile incelenmesi gereken renk, plastik gösterge içinde biçim ya da doku ile birleşmez ise deneysel bir varlığından söz edilemez. Renkler, göstergebilimsel çözümlemede bütündeki yerlerine göre anlam kazanmaktadır.

\subsubsection{Doku}

Groupe $\mu$ (mü)'ye kadar görsel incelemelerde üzerinde çok fazla durulmamış bir yapı olan doku, plastik göstergeler içerisinde özel bir öneme sahiptir. Doku, üç boyutluluk, dokunsallık ve dışavurum izlenimi verebilmektedir. Renk gibi bir yüzey niteliğinde olan doku, izlenen nesne ile izleyici arasında bir tür mesafe oluşturmaktadır. Örneğin tablolar dokularının yoğun olmaları nedeniyle daha dokunsal olmalarına rağmen, dergi fotoğrafları, yüzeylerinin kaygan ve düz olmaları dolayısıyla ince bir dokuya dolayısıyla da daha az dokunsallığa sahiptir.

\subsubsection{Biçim}

Groupe $\mu$ (mü)'ye göre, göstergebilimsel bir betimleme, öncelikle görsel sistemin fizyolojik bir araştırmasını gerektirmektedir. Biçimlerin niteliği de bu sistemin bir sonucudur. Çizgi, fon, sınır, alan, çevre çizgisi, yüzey gibi görsel dürtüler algılamayı yönlendirmektedir. Bu öğeler görsel sistemin algı niteliklerine bağlı olarak ortaya 
çıkmaktadır. Bir bakıma görsel dilbilgisinin öğeleri olarak da tanımlayabileceğimiz bu öğeler, dilsel dizgedeki sözcükler gibi kimi yapıların yerine geçmektedir.

\subsection{Ikonik Göstergeler}

Evrende bulunan nesnelerin imge düzleminde dönüştürülmüş ya da yeniden oluşturulmuş biçimi olarak tanımlanan ikonik göstergelerin görsel metinde değerlendirilmelerinin nedeni, türünün tek örneği olmaması ve dolayısıyla da kendisi dışında bir düşünceye gönderme yapıyor olmasıdır. Tanıdığımız varlıklar ya da betiler olan ikonik göstergelerin belirlenmesi, genellikle imgenin betimlenmesi sırasında gerçekleşmektedir. Görsel söylem ancak bunların içerik düzlemlerindeki anlamlarının ve yan anlamlarının ortaya çıkartılması ile çözümlenebilmektedir (İnceoğlu ve Çomak, 2009, 302). Zira reklamlarda ikonik göstergelere sıklıkla rastlanmaktadır. Sözgelimi, herhangi bir reklamda kullanılan kırmızı renk, ilk bakışta olmasa da reklamın kurgusu içinde, yan anlamda tehlikeyi çağrıştırabilmektedir.

İmgede, öncelikle ikonik göstergeler dikkat çekse de renk, biçim, doku gibi plastik göstergelerin, yan anlamların belirlenmesinde ve çağrışımların yaratılmasında ağır basarak, ikonik göstergelerin belirlenmesine rehberlik etmeleri nedeniyle, çözümlemeye plastik göstergeler ile başlamak daha yararlı olacaktır (Yücel, 2013,96). Dilsel iletinin kullanımı da diğer göstergeler kadar yaygındır. Reklamda, sözel unsurları görsel olarak betimleyen başlık, slogan, metin gibi sözel unsurların tümüne illüstrasyon adı verilmektedir (Becer, 1999, 210). Dilsel göstergenin yer almadığı reklam, logo, afiş, marka görmek neredeyse imkansızdır. Groupe $\mu$ (mü)'ye göre sözel ya da yazılı iletiler olmadan da söylem çc̈zümlemesi yapılabilmesine karşın görsel iletiye eşlik etmeleri durumunda söylemin çözümlenmesi kolaylaşmaktadır (Yücel, 2013, 172). Barthes da sözel ya da yazılı dilin eşlik etmediği bir imgeyi bulmanın zorluğundan değinmiştir. İmge dilsel iletiyi destekleyerek, kullanımını ve yorumunu biçimlendirmektedir. İmgenin araçlarından biri olan dil, çoğu kez imgeye eşlik etmektedir. Örneğin bir tablonun adı bakış açımızı şekillendirecektir, dolayısıyla dil imgenin yorumlanmasında belirleyicidir (Yücel, 2013,178181). Tüm bu gösterge dizgeleri yan anlamsal kodlar olan kültürel değerlerle ya da ideolojiyle eklemlenmektedir (Gottdiener, 2005, 31). İncelenen reklam metinlerinde de plastik ve ikonik göstergelerden yola çıkarak, yaratılmaya çalışslan tüketim ideolojisi analiz edilmiş̧ir.

\section{Bulgular}

\subsection{Kelebek Mobilya Salon Takımı Reklam Çözümlemesi}

Kelebek Mobilya dergi reklamı metni, görsel metin, başlık, yazılı metin ve slogandan oluşmaktadır. Görsel metninde, doğanın içerisinde, sade ve modern tasarımlı bir evin salonu görülmektedir. İki sayfadan oluşan reklam iletisinde dilsel iletide yer alan göstergeler ile görsel iletide yer alan göstergeler arasında bir bütünlük gözlemlenmektedir. Görsel metnin sol tarafinda "Doğallık hep moda" sloganına ve hemen altında "Kelebek Mobilya'dan yeni, doğal Angelic koleksiyonu. Kelebek mobilyanın yeni koleksiyonu Angelic, eskitme meşe yüzeyi ve şık tasarımıyla evinize doğallı̆̆ getiriyor. Angelic koleksiyonunu estetik ve hiç modası geçmeyen doğal tasarımuyla yillarca huzurla ve beğeniyle kullanacaksınız" metnine yer verilmiş̧ir. 


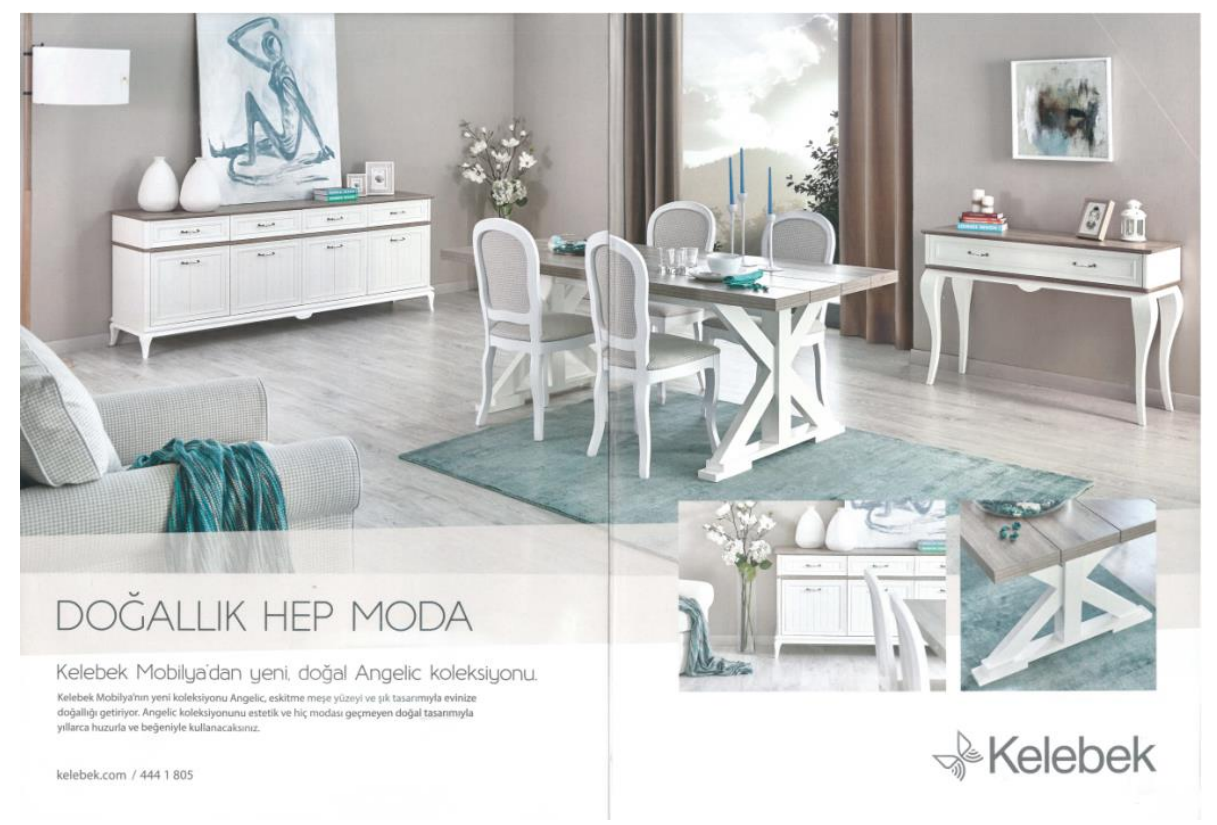

Resim1: Kelebek Mobilya Salon Takımı Reklamı

Reklamda yaşam tarzını yansıtan mobilyaların doğallık göstergesi ile birlikte kodlandığı görülmektedir. Modelin adı olan ve melek gibi anlamına gelen Angelic, melek kelimesinin çağrıştırdığı saf, temiz gibi anlamlardan hareketle olumlu bir çağrışım yaratmaktadır. Dilsel iletide ağırlıklı olarak vurgulanan doğallık, başta sloganda olmak üzere metinde de görülmektedir. Ayrıca metin yeni, koleksiyon, şlk, tasarım, estetik, huzur, beğeni gibi olumlu çağrışımlar yaratan dilsel göstergeler ile desteklenmektedir.

Reklam metninde doğallığın en önemli göstergesi, evin penceresinden görünen doğa manzarasıdır. Ağaçların pencerenin hemen önünde oluşu ve manzarada yer alan dağın yakın bir mesafede oluşu, evin doğa ile iç içe olduğunu göstermektedir. Reklam metninde gösterilen bu ev kent çeperinde, kentten uzakta "uydu kent" görünümündedir. Uydu kentler; kentin eski haline duyulan özlemlerle şekillenmiş, güvenli ve akıllı konutlardır. Bir şehirden ne bekleniyorsa bireylerin ona sahip olabileceği, kent içindeki bu yeni kentler, bu dünyada tesis edilememiş orta sınıf beklentilerinin tümüne karşılık gelen mekansalayrışmanın ifadesidir (Yücebaş, 2013, 22).

Kentin dışında, yeni orta sınıfın zenginliğiyle, yaşam tarzıyla örtüşen bu konutun bulunduğu mekanın içi de doğallık göstergeleriyle bezelidir. Doğa adeta evin içine sirayet etmiştir. Zeminde doğallık hissi uyandıran ve ahşap görünüme sahip laminant parke kullanılmıştır. Reklamda görünen en belirgin aydınlatma nesnesi olan lambader sade görüntüsü ve ahşap ayağı ile doğallığın bir diğer göstergesidir. Dresuarın üzerinde bulunan gaz lambası ise eve doğal bir hava katmak amacıyla kullanılmış bir diğer aksesuardır. Reklamda 1şığın doğal kaynağı olan güneşin aydınlatma nesnesi olarak kullanılması da reklamdaki doğallığın en belirgin göstergelerinden biridir. Reklamın genelinde doğallığın vurgulanması yapay olanı doğayla ilişkilendirerek tüketimin masumlaştırılması olarak okunabilir (Fiske, 2003, 232). Williamson (2001, 127)'a göre "doğa kültür içinde bir simgedir." Bu reklam metninde de doğaya ait unsurların doğanın sahip olduğu kusursuzluk niteliğini çağrıştırmak amacıyla kullanıldığı görülmektedir.

Beyaz ve kahverengiden oluşan mobilyalarda beyaz renk, temizliğin, saflığın, masumiyetin ve asaletin göstergesidir (Yengin, 1997, 202). Tek başına kullanımında soğuk bir renk olan beyaz, reklamda ahşap üzerinde olması ve farklı göstergeler ile birlikte kullanılmasıyla doğal ve sıcak bir görünüme kavuşturulmuştur. Beyazdan 
sonra mobilyada kullanılan bir diğer renk olan kahverengi, doğayı oluşturan en temel renklerden biri olması nedeniyle doğallık hissini güçlü bir şekilde vermektedir. Evde belirgin bir diğer renk turkuazdır. Turkuaz, sakinlik veren ve dinlendirici bir renktir (Yolcu, 2002, 655). Aynı zamanda doğada sıklıkla görülen mavi rengin bir tonu olan turkuazın reklam metninde, sakinliğin yanında doğallığı da vurguladığg belirtilebilir.

Reklamda evdeki aksesuarlar doğallığın yanında aynı zamanda şıklık göstergesidir. Örneğin, duvarlarda “eskiz” ve "soyut” türlerdeki tablolar göze çarpmaktadır. Bir karalama çizimi olarak düşünülebilecek taslak olan eskiz ile nonfigüratif sanat olarak da adlandırabileceğimiz soyut çalışma örnekleri ile karşımıza çıkan duvarlardaki tablolar, bir taraftan mekana estetik bir hava katarak şıklığı simgelerken bir taraftan da böyle bir evde oturanların entelektüel seviyelerine dair ipuçları vererek kültürel ve ekonomik sermayelerine ve dolayısıyla beğenilerine gönderme yapmaktadır. Bourdieu’ye göre “beğeni sınıflandırır ve sınıflandırıcıyı sınıflandırır”. Tüketim ve yaşam tarzı tercihleri, meslek ve sınıf fraksiyonlarına denk düşerek ayrım yapan yargılar içermektedir. Bu ayrıştırma ile gelen farklılaşmanın tüketim kültürünün en önemli silahı olduğu unutulmamalıdır (Bourdieu, 1984; Featherstone, 2005, 45). Bu farklılık işaretleri, bireyin ya da ailenin zevkinin, beğenisinin ve kimliğinin ifadesi olarak sıklıkla vurgulanan giyim ya da araba tercihlerinin yanı sıra incelenen reklamda olduğu gibi ev dekorasyonuyla da yansıtılmaktadır (Ayata, 2012, 54). Özellikle konut içi dekorasyonda tercih edilen tüm objelerin renk, doku, malzeme gibi nitelikleri ve bir arada kullanılmaları sonucunda ortaya çıkan dekorasyon tarzı bireylerin yaşam tarzlarıyla ilgili önemli ipuçları sunmaktadır.

Bir dergi reklamı olması nedeniyle sayfanın yapısından (matlığından) kaynaklanan soğukluk hissi plastik göstergeler olan renk ve doku ile aşılmıştır. Mobilyalardaki eskitme meşe yüzey, koltuk ve sandalyelerin pamuksu kumaşı, koltuğun üzerindeki polar ve halının dokusu ve renkleri gibi plastik göstergeler ile doğallık ve yumuşaklık hissi uyandırarak dokunma hissi veren bir atmosfer yaratılmıştır. Sonuç olarak reklam metninde manzaradan, kullanılan aksesuarlara kadar her bir ayrıntı, şıklığı ve estetiği elden bırakmadan, bir yaşam tarzı olarak sunulan doğallığın göstergeleri olarak kodlanmıştır.

\subsection{Lineadecor Mutfak Reklamı Çözümlemesi}

Lineadecor mutfak reklamı metni, görsel metin, başlık, yazılı metin ve slogandan oluşmaktadır. Görsel metin, doğanın içerisinde eğlenceli ve enerjik bir atmosfere sahip modern tasarımlı bir mutfaktan oluşmaktadır. İki sayfadan oluşan reklam iletisinde dilsel iletide yer alan göstergeler ile görsel iletide yer alan göstergeler arasında bir bütünlük bulunmaktadır. Görsel metnin sol tarafında “Hiç mutfakta oyun oynadınız mı?” sloganı ve sağ tarafında "Neo'nun enerjik renkleri, farklı formları ve yenilikçi detaylarıyla mutfă̆ınızı baştan yaratın. Birbirinden lezzetli yemekler hazırlayın, yepyeni tarifler deneyin, arkadaşlarınızla sohbet edin, kısacası içinizdeki çocuğu dinleyin ve sizi mutlu eden ne varsa hepsine mutlaka kulak verin.” metni yer almaktadır. 


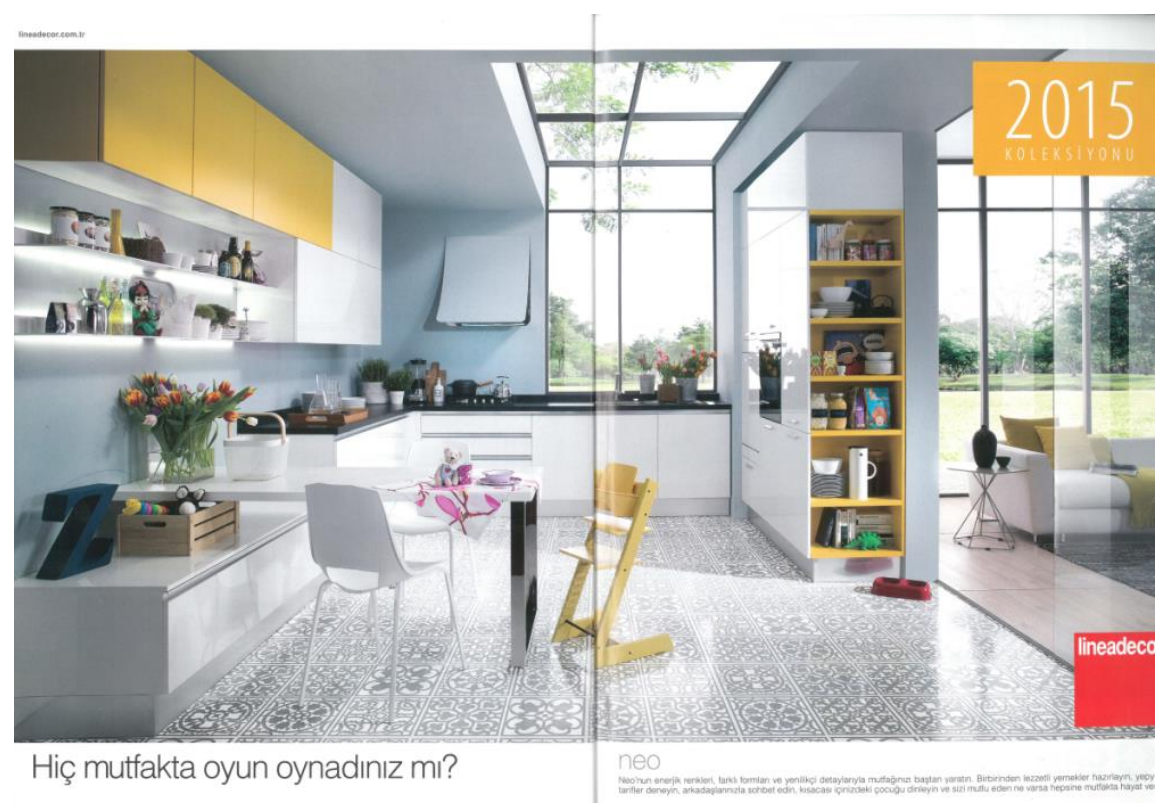

Resim 2: Lineadecor Mutfak Reklamı

Reklamdaki dilsel ileti de başta slogandaki oyun kelimesi olmak üzere, enerjik, farkl, yenilikçi, lezzetli, yepyeni, sohbet, çocuk, mutlu kelimeleri ile olumlu çağrışımlar yaratmaktadır. Modele verilen ve Yunanca neos kelimesinden türeyerek yeni anlamına gelen neo sözcüğü de yazılı metinde farkll, yenilikçi, yepyeni kelimeleri ile desteklemektedir. Bu kez reklamda lüks ve modern yaşam tarzı tüketiciye yenilik ve eğlence vurgusu ile birlikte sunulmaktadır.

Yaşam tarzının en önemli göstergelerinden biri olan ve aynı zamanda ekonomik ve kültürel sınıfsal ayrışmanın da en önemli unsuru olan mekânsal ayrışma bu reklamda da dikkat çekmektedir. Reklamı yapılan ürün, "sıradan" insanların yaşadıkları mekânlardan oldukça farklı bir mekanda sergilenmektedir. Evin yakınlarında başka bir binanın görünmüyor olması ve bahçesi müstakil bir ev görünümü vermektedir. Bu da mutfağı kullanan ailenin sahip olduğu yüksek gelir seviyesi ve statünün göstergelerinden biridir. Zira reklam metni, gerek kentten uzaktaki mekân algısı ve gerekse konutun içindeki göstergelerle zenginliğe ve üst sosyo-ekonomik duruma işaret etmektedir. Reklamda gösterilen konut da direkt bahçeye açılan, doğayla içe içe ve muhtemelen kentin karmaşasından uzakta, yalıtılmış bir ortamda yer almaktadır.

Mutfaktaki modern görüntüyü enerji ve eğlence ile birlikte veren reklam metni ile tüketiciye eğlenceli ve enerjik bir yaşam tarzı sunulmaktadır. Reklamda baskın olarak göze çarpan renk sarıdır. Sarı reklamda eğlencenin ve enerjinin rengi olarak kodlanmıştır. Sıcak bir renk olan sarı mutlulukla eşdeğer tutulduğu için eğlence içerikli ve çocuklara yönelik ürünlerde sıklıkla kullanılmaktadır (Yücel, 2013, 118). Ayrıca uyarıcı ve iştah açıcı özelliği ile sarı ve sarı gibi sıcak renkler olan kırmızı ile turuncu, reklamlarda mutfak tasarımı için tercih edilen renklerdir. Görselde, masada, mutfak tezgahında ve raflarda bulunan çiçekler sarı oluşunun verdiği enerji ile birlikte eve sıcak bir hava katılmaya çalışılmıştır. Özetle, reklam metninde mutfağın oyun ve eğlence ile özdeşleştirilmesi nedeniyle sarı renk kullanımı tercih edilmiştir.

Mutfak dolaplarındaki bir diğer renk olan, masa ve sandalyelerde de kullanılan beyaz, hijyene en ihtiyaç duyulan yerlerden biri olan mutfakta temizliğin göstergesi olarak kodlanmıştır. Mutfak tezgahı için tercih edilen modernliğin, şıklığın, soyluluğun, seçkinliğin ve zarafetin rengi olan siyah mutfaktaki şık tasarımı bütünleyen bir 
göstergedir. Aynı zamanda siyah aşırı lüksü de simgelemektedir (Yengin, 1997, 201). Ayrıca aksesuarlarda kullanılan siyah, eğlencenin, enerjinin yanı sıra evde yaratılmak istenen modern ve seçkin havayı desteklemektir.

Reklamda manzara ile görünen ve dikkat çekici renklerden biri de yeşildir. Göstergebilimin en temel ikili karşıtlığı olan doğa ve kültür karşıtllığının (Williamson, 2001, 128) sunulduğu reklamda, büyük pencerelerin yanı sıra, cam tavan ve salonda görünen cam duvarlar ile doğa evin içine sirayet etmiştir. Doğa ve yeşil, saflığı, temizliği, sağlığı, bereketi, gençliği, neşeyi ve özgürlüğü simgelemektedir (Yengin, 1997, 202). Tıpk1 sarı gibi tabiatın da rengi olan ve canlılığı simgeleyen yeşil ayrıca mutfaktaki oyuncaklar ve bitkilerde de görülmektedir.

Havalandırmanın açık olması, ocakta bir tencere ile çaydanlığın olması, tepside bulunan ve içerisinde az miktarda su kalan sürahi mutfağın kullanılır durumda olduğunu gösteren göstergelerdir. Ancak reklamdaki göstergeler bir kişinin orada yaşadığının ipucu olsa da "fakat o orda bulunmayandır." Resmin perspektifi izleyici kişi ile reklamdaki mutfak arasında "ortak uzaysal bir ilişki kurmak" için böyle tasarlanmıştır (Williamson, 2001, 80). Bu sayede izleyicinin boş olan alanı doldurması beklenmektedir. Böylece evin kullanım halinde olduğunu göstermek amacıyla kullanılan tüm göstergeler ile daha doğal ve gerçekçi bir görüntü yakalanmıştır.

Mutfak dolaplarının raflarında görünen ve bir mutfak için alışılmışın dışında oldukça fazla olan kitaplar ile koltuğun üzerinde açık bırakılmış dergi, ev sahiplerinin entelektüel seviyelerine ilişkin ipucu vermektedir. Ayrıca oyuncak dolu kasa, mama sandalyesi ve raflardaki oyuncaklar, ailenin çocuk sahibi olduğunu göstermektedir. Böylece reklam aracılığıyla kapitalizmin temel tüketim birimi olarak gördüğ̈̈ ailenin varlığı kutsanmaktadır.

Özetle reklam metninde, reklamı yapılan ürüne sahip olanların ya da olabileceklerin üst sosyo-ekonomik sınıftan insanlar oldukları, kentin dışında ve kentin karmaşasından uzak evlerinde ve elbette reklamı yapılan ürün aracılığıyla mutfakta keyifli ve hatta oyun tadında 'eğlenceli' zaman geçirebilecekleri vaadi sunulmaktadır. Teorisyenler, günümüz toplumunu, "postmodern toplum”, "enformasyon toplumu”, "kapitalist ötesi toplum", "tüketim toplumu" gibi çeşitli şekillerde tanımlansa da eğlence toplumuna doğru evrildiğimiz de bir hakikat olarak karşımızda durmaktadır. Zillman $(2000,17)$ içinde bulunulan durumu, "Eğlence Çağı Huzurunuzda!" ifadesiyle özetlemektedir. Nitekim günümüzün postmodern tüketicisi için hayatın içinde oyun ve eğlence deneyimleri önem kazanmıştır (Odabaşı, 2006, 157). Böylece insanlar varolan gerçekliği/koşulları sorgulamaktan alıkonulmakta, geçmişi ya da geleceği düşünmek yerine şimdiye ve yaşadıkları ana odaklanmaktadırlar.

\subsection{Baqlar's Yatak Odası Reklam Çözümlemesi}

Baqlar's Yatak Odası reklam metni, görsel metinden oluşmaktadır. Görsel metinde, modern ve klasik bir görünüme sahip avangart bir yatak odası görülmektedir. İki sayfadan oluşan reklam iletisinde dilsel ileti adına yer alan marka adı görsel metnin sağ alt tarafindadır. 


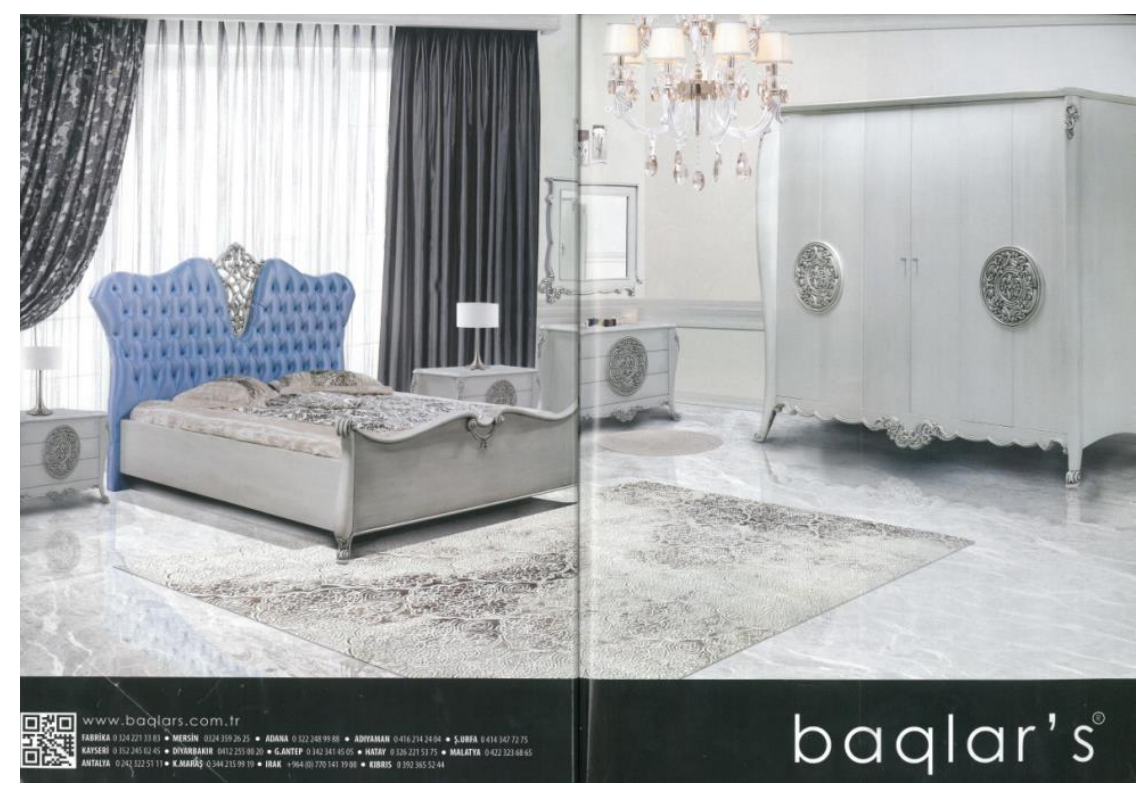

Resim 3: Baqlar's Yatak Odası Reklamı

Reklamdaki avangart yatak odası takımı, zeminden avizeye, yatak örtüsünden halıya kadar lüks bir yaşam tarzı sunmaktadır. Reklamda yatağın başlığının mavi oluşu tesadüf değildir. Gökyüzünü, huzuru, denizi, özgürlüğü çağrıştıran mavi sakinleştirici ve dinlendirici etkiye sahiptir. Aynı zamanda mavi renk Osmanlı tarzının günümüzde mobilyalara uyarlanmış tasarımlarında da sıkça kullanılmaktadır (Elden, vd., 2014, 827). Reklam metnindeki Osmanlı tarzını yansıtan yatak başında bu rengin kullanılması ile eski ve yeni arasında bir bağ kurulmaya çalışılmıştır.

Reklamda bir diğer dikkat çekici unsur olan altın sarısı ve beyazdan oluşan kristal avize de zenginliğin göstergeleri olarak okunmaktadır. Paranın, varsıllığın, kraliyetin ve gücün göstergesi olan altın sarısı (Yücel, 2013, 18-20) verilmek istenen lüks yaşam tarzı mesajını destekler niteliktedir. Bir diğer aydınlatma nesnesi olan ve yatağın her iki tarafindaki komodinlerin üzerinde yer alan abajurlar sade görünümlerine rağmen gümüş grisi renkleri ile yan anlamda varsıllı̆̆ı simgelemektedir (Yücel, 2013, 125).

Bir saray odasını andıran yatak odası takımında oldukça gösterişli olan başıl̆ğın orta kısmındaki dikkat çekici ayrınt1, gümüş grisi rengiyle ihtişamlı bir görünüm sunmaktadır. Tüm mobilyaya hakim olan gösterişli işlemeler yatağın ucundaki bir saraydaki kapı tokmağını andıran işlemede olduğu gibi soyluluğun, gösterişin, zenginliğin, farklılı̆̆ın göstergeleridir. Saten bir dokuya sahip olduğu anlaşılan şık desenli yatak örtüsü ve kendisiyle benzer desene sahip olan halı varsıllığın farklı göstergeleridir. Yatak örtüsünde pamuksu bir kumaş yerine parlak saten bir dokunun tercih edilmesi reklam metnindeki varsılllı̆ı̆ın plastik göstergelerinden biridir.

Reklamdaki bir diğer önemli ayrıntı da, zeminin neredeyse ayna etkisi yaratan oldukça parlak mermer yüzeyidir. Parlak mermer yüzey ile sunulan bu ihtişamlı görüntü lüksün başka bir göstergesidir. Her göstergenin tarihsel, kültürel ve ideolojik bir anlamı bulunmaktadır. Bu anlam toplumdan topluma değişebilmektedir. Osmanlı tarihinde yer alan saray hayatı ihtişamı, lüksü, varsıllığı hatırlatmaktadır. Reklamda bir saray odası görüntüsüyle sunulan bu yatak odası da tüketicinin kültürel birikiminden yararlanarak yan anlamda lüks bir yaşam tarzını sergilemektedir.

Özetle reklamdaki mekan ve mekanın tasarımında kullanılan Osmanlı tarzını yansıtan mobilyalar ve diğer objeler, renkler ve dokular zenginliği ve lüksü çağrıştıran unsurlardır. Günümüz postmodern toplumunda sıkça 
görüldüğü üzere reklamda da Osmanlı kültürel öğelerini yansıtan nesnelerin, zenginliği çağrıştıran kodlarla verilmesi ürünü kullanacak kişilerin "sultanlara yakışır" konforlu, rahat ve lüks bir yaşam süreceklerinin göstergesi olarak görülebilir. Böylece reklam aracılığıyla izleyicide ‘belirli bir yaşam tarzı hayali’ yaratılmaktadır.

\subsection{Orka Banyo Reklam Çözümlemesi}

Orka banyo reklam metni, görsel metin, başlık, yazılı metin ve slogandan oluşmaktadır. Görsel metinde, deniz manzaralı ve şık tasarımlı lüks bir banyo görülmektedir. Tek sayfadan oluşan reklam iletisinde dilsel iletide yer alan göstergeler ile görsel iletide yer alan göstergeler arasında bir bütünlük bulunmaktadır. Görsel metnin sağ üstünde "Banyoda mükemmeli arayanlar için..." sloganı, altında ise "Altın çerçeveli desenli aynası ve dekoratif altın çizgileri ile banyolarda country tarzının şık bir yansıması. ORKA IHLARA ile evler mütevazi bir saraya dönüşüyor. ORKA Banyo 2015 Koleksiyonu birbirinden şık ve fonksiyonel yüzlerce çeşit ve renk seçenekleri, geniş stok ve anında teslim avantajı ile satış noktalarımızda sizi bekliyor. ORKA Banyo ürünleri tüm Türkiye'de 300'den fazla satış noktasında, 1 milyondan fazla evde ve 44 ülkede tüketiciyle buluşuyor." metni yer almaktadır.

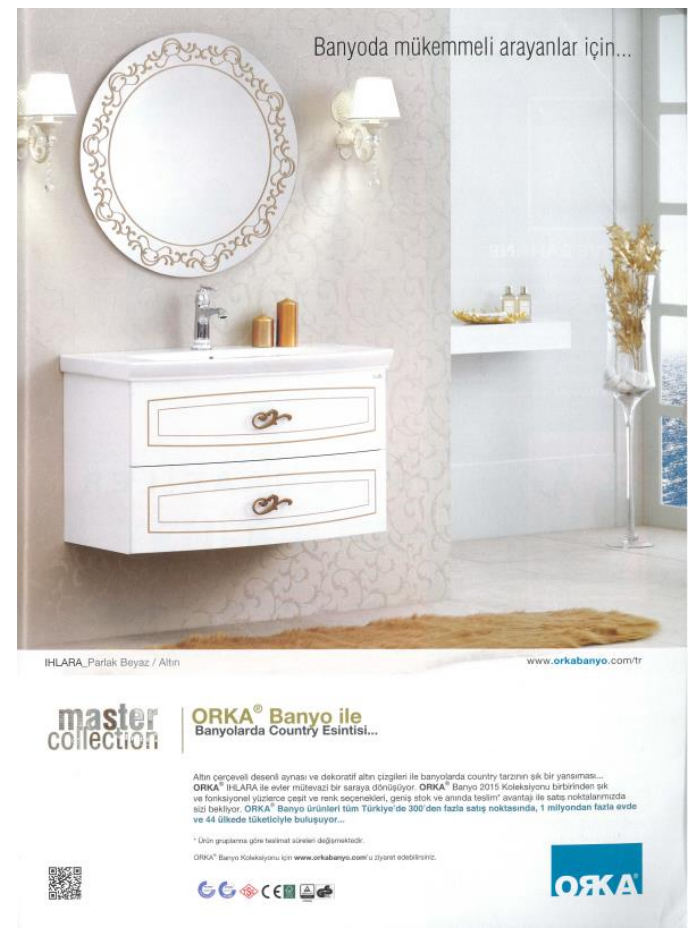

Resim 4: Orka Banyo Reklamı

Slogandaki "mükemmellik" ifadesinde olduğu gibi dilsel iletide yer alan; altın, desen, dekoratif, şık, saray, fonksiyonel, çeşit, seçenek, genişs stok, avantaj, koleksiyon gibi olumlu çağrışımlar yaratan ifadeler ile reklam desteklenmektedir. Kullanılan kelimelerde dikkat çeken bir başka özellik ise mükemmellik, şıklık, saray gibi lüks yaşam tarzını çağrıştıran kelimelerin sıklıkla kullanımına karşın temel ihtiyaçlara ilişkin yalnızca fonksiyonel kelimesinin geçmesidir. Bu, günümüz tüketim ve reklamcılık anlayışının bir göstergesidir. Bu anlayış çerçevesinde reklamlarda sıklıkla "estetik deneyimlere" vurgu yapılırken ürününün işlevsel faydaları, sembolik niteliklerini destekleyecek şekilde yüzeysel olarak belirtilmektedir (Odabaşı, 2006, 165). Ayrıca reklamlarda "saray" metaforunun günümüz dekorasyonu ile harmanlanarak kullanıldığg da sıklıkla görülmektedir (Elden, vd. 
2014). Böylece reklam metni ile günümüz mekanlarında saraya ilişkin detaylar kullanılarak bireylerde lüks algısı yaratılmak istenmektedir.

Ağırlıklı olarak beyaz ve altın sarısı renginden oluşan banyo lüks bir yaşama ait göstergelerden oluşmaktadır. Reklamdaki, mobilyada, duvarlarda ve zeminde ağırlıklı olarak kullanılan renk beyazdır. Temizliğin göstergesi olarak kabul edilen beyaz, daha derine inildiğinde, sınıf ayrımlarını simgeleyen bir renktir. Reklamda dikkat çeken bir diğer renk ise altın sarısıdır. İşlevsellikten öte şıklığın önemsendiği tasarımda, banyo aynasının etrafı altın rengi süslemeler ile çevrilmiştir. Banyo musluğunun alt kısmında altın renkli işlemelerin olması abartılan gösterişi destekler niteliktedir. Musluğun yanında bulunan altın rengi mumlar da banyodaki lüksün farklı göstergeleridir. Yerde duran banyo paspası da banyodaki ihtişama uyumlu bir şekilde altın sarısı rengindedir. Vazonun içerisindeki yapraklar varsıllığın göstergelerine uyumlu olarak altın sarısı rengindedirler. Ayrıca burada beyaz renge eşlik eden altın sarısı paranın varsıllığın, kraliyetin ve gücün göstergesidir (Yücel, 2013, 18-20).

Düşük gelir grubundaki insanların banyolarında sahip olamayacakları bir deniz manzarası ve ancak bir evin odalarından birinde olabilecek Fransız penceresi, duvar kâğıdı ve kristal taşlı aplikler reklam metnindeki varsıllığın en güçlü diğer göstergeleridir. Böylesine bir banyoya sahip olan insanların yüksek gelir seviyelerine ve statülerine işaret edilerek hedef kitleye lüks bir yaşam standardı vaat edilmektedir. Tek başına dahi bir lüks göstergesi olan deniz manzarası, reklam metninde güneş 1şıklarının etkisi ile parıltılı bir görüntü ile sunulmaktadır.

Nitekim, tüm reklam metnine uygulanan göstergebilimsel analiz sonucunda mükemmellik sloganı ve reklam metninde aktarılan evleri saraya çevirme vaadiyle banyonun lüks bir yaşam tarzını çağrıştırdığı vurgulanmaktadır. İncelenen reklam metninde bu banyoya sahip olanların/olabileceklerin sosyo-ekonomik konumuna işaret eden göstergelerle, bir diğer deyişle zenginliğin sunumuna dair söylem ile izleyiciler zenginliğe ve lüks yaşama öykündürülmektedir.

\subsection{Origami Oturma Odası Reklam Çözümlemesi}

Origami oturma odası reklam metni, görsel metinden oluşmaktadır. Görsel metinde, avangard tarzda döşenmiş bir oturma odası bulunmaktadır. İki sayfadan oluşan reklamda slogan ve reklam metni bulunmamaktadır. Reklam metninin sol üst köşesinde marka ismi yer almaktadır.

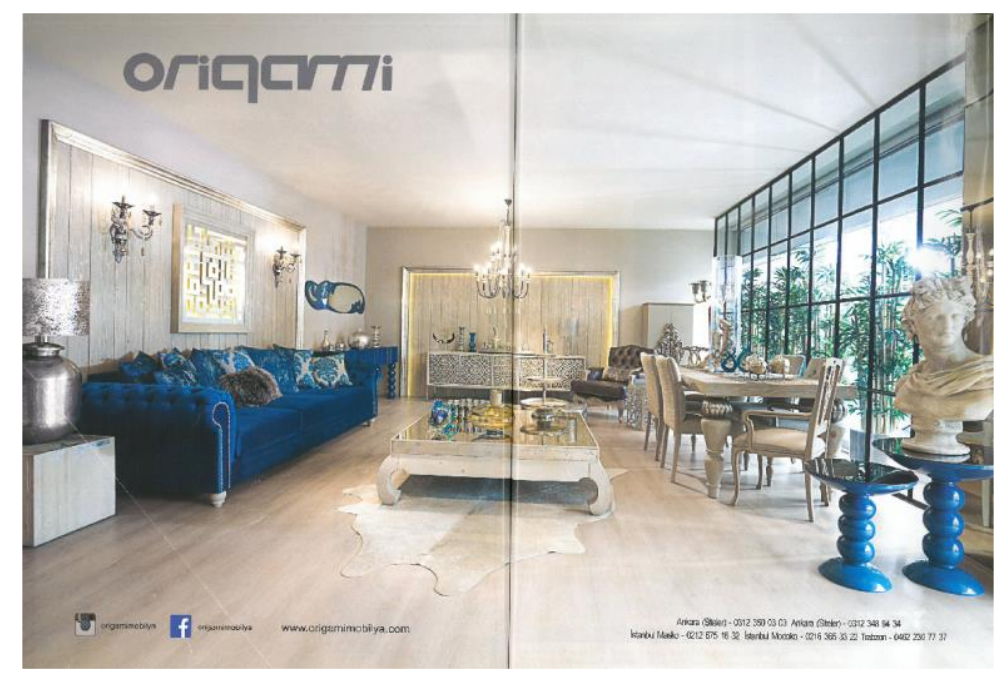

Resim 5. Origami Oturma Odası Reklamı 
Reklam metnine klasik bir tarz hakimdir ancak dekorasyonda modern ve klasik unsurların bir arada kullandığı objeler dikkat çekmektedir.Örneğin, reklamda yer alan koltuk, konsol, masa ve üzerlerindeki aksesuarlar klasik tarzı yansıtan objelerken; sol alt köşede görülen sehpa, üzerindeki abajur ve cam duvar ise modern tarzdadır. Bunlara ek olarak, mekanda yer alan çok sayıda aydınlatmadan kristal taşlı avize, aplikler ve şamdanlar klasik bir tarzı simgelerken; abajurlar ve led ışıkların modern bir tasarımda olduğu görülmektedir.

Reklamdaki bir diğer ikili karşıtlık ise eski ve yeninin bir arada kullanılmasıdır. Reklam metninde, eskiyi simgeleyen en belirgin görsellerden biri, orta sehpanın altındaki posttur. Geçmişi insanlık tarihi kadar eski olan halının ilk şekli olan post, reklamda özellikle tercih edilmiştir. Tüplü gaz lambası formundaki abajur ise eski olanın modernize edilmiş halini örneklemektedir.

Reklam metninde göze çarpan bir diğer karşıtlık ise doğu ve batıya ait mimari unsurların bir arada kullanılmasıdır. Söz gelimi, konsolun üzerinde bulunan hilal şeklindeki aksesuar, masanın ve dresuarın üzerinde bulunan gümüş renkli aksesuarlar oryantalist akımı simgelerken; sağ köşedeki mermer büst batı sanatını örneklemektedir. Tüm bu ikilikler postmodernizm etkisindeki reklamların tüketicisine sunduğu teklik değil, çeşitlilik ile açıklanabilir (Özbek, 2005, 16).

Görsel metindeki mekanın genişliği, yüksek tavan, cam duvar ve bahçe manzarası lüks bir konutun göstergeleridir. Yalnızca konutların değil; konutların dekorasyonlarının da birer yaşam tarzı göstergesi olmasından hareketle, reklamdaki konutun dekorasyonun da lüks objelerle bezeli olduğu görülmektedir. Söz gelimi, salondaki konsol ve dolabın gümüş renkli gösterişli işlemeleri, masanın ve sehpaların formu, deri berjer ve kadife koltuk, kristal taşlı avize ve aplikler, şamdanlar, gümüş renkli aksesuarlar ve büst lüks ve ihtişamı yansıtan şıklık göstergeleridir. Tüm bu göstergeler, konutun yüksek gelir grubuna sahip kişilere ait olduğunu vurgulamaktadır.

Plastik göstergelere bakıldığında bir dergi reklamı olması nedeniyle sayfanın yapısından (matlığından) kaynaklanan soğukluk hissi, görselin sağ tarafında ön planda olan büstün mermer malzemesi ve dokusu ile pekiştirilirken; görselin sol tarafındaki kadife koltuk ve üzerindeki peluş yastık ile bu his yumuşatılmaktadır.

Reklam metninin genelinde mekanda ağırlıklı olarak mavi, altın sarısı ve gümüş renginin kullanıldığı görülmektedir. Mavi renk, koltuk, sehpalar ve aksesuarlarda kullanılmıştır. Soyluluğun, varsıllığın rengi olarak tanımlanan mavi (Yengin, 1997, 200), özellikle kadife kumaşlı koltuk ve damask desenli kırlentler de dikkat çekmektedir. Damask deseni, oryantalist bir dekorasyon tarzını yansıtırken, kadife kumaş da, Osmanlı döneminde yüksek gelirli kesim tarafından sıklıkla kullanılan bir kumaş türüdür (Elden, 2014, 823). Reklam metnindeki diğer baskın reknkler ise altın sarısı ve gümüş grisidir. Aksesuarlarda ve led 1şıklarda ön plana çıkan altın sarısı ihtişamı ve zenginliği simgelemekteyken (Elden, 2014, 825), gümüş grisi de yan anlamda varsıllı̆̆ı simgelemektedir (Yücel, 2013, 125).

Sonuç olarak, gerçekleştirilen göstergebilimsel analizle ele alınan ve reklamdaki mekana ilişkin ipucu veren objeler, objelerin kullanım şekli, objelerin karşıtlık ilişkileri, renkleri, dokuları ile ilişkili tüm göstergeler gösterişçi, lüks bir yaşam tarzının birer yansımasıdır.

\section{Sonuç}

Zenginlik ve lüks yaşam tüm medya içeriklerinin ortak anlatılarından biridir ve neredeyse zenginlik göstergeleri olmaksızın üretilmiş bir medya içeriğine rastlamak mümkün değildir. Özellikle reklamlar ve reklamın tüketim kültüründe oynadığı rol düşünüldüğünde zenginliğe dair göstergelerin ve buna denk düşen yaşam tarzının reklamlarda ne denli yer aldığını tahmin etmek zor olmayacaktır. 
Yaşam tarzlarının tüketiciler tarafından tüketimle biçimlendirildiği günümüz toplumunda bireyler yaşam tarzlarını yalnızca dış görünüşleri ile değil evleri, mobilyaları ve dekorasyonları ile tamamlamaktadır (Featherstone, 2005, 145). Bu bağlamda, çalışmada bireylerin yaşam tarzlarının en önemli göstergelerinden biri olan konut dekorasyonları ile ilgili reklamlar çözümlenmiştir. Reklamlar çözümlenirken öncelikle konutun yer aldığı konum, daha sonra konut içindeki dekorasyonda kullanılan objelerin renk, biçim ve tasarım özellikleri doğrultusunda bir değerlendirme yapılmıştır.

Reklamlardaki konutların konumsal olarak ortak özelliği, kalabalık şehir ortamında olmamalarıdır. Reklamı yapılan konutlar, düşük ya da orta gelir grubuna dahil insanların yaşadıkları yerleşim bölgelerinden oldukça farklı konumlarda sergilenmektedir. Ekonomik ve kültürel ayrışmayı imleyen bu mekansal farklılık, 1980 sonrası uygulanan politikalarla özellikle hizmet sektörünün genişlemesi ile ortaya çıkan ve kendini beğeni ve üslup konusunda diğer sınıflardan farklılaştırmaya çalışan “yeni orta sınıf”la ilişkilidir. Zira tüm alanlarda farklılaşmayı önceleyen ve yaşam karşısında aşırı oburluk sergileyen bu sınıf için, konut da bir seçkinlik ve yaşam tarzı göstergesidir. Özellikle 1990'larda ortaya yeni orta sınıfın, alt sınıflardan ayrışarak tecrit edilmiş bir bölgeye kaçışı ve kargaşa içerisindeki tehditkar bir hayattan kendini soyutlama zihniyetinin bir uzantısı olarak ortaya çıan uydu kentler (Ayata, 2012, 54), incelenen reklam metinlerinde göze çarpmaktadırlar. Tüm reklam metinlerin, konutların konumları ve konut tipleri ile göstergelerle zenginliğe ve üst sosyo-ekonomik statüye işaret edilmektedir.

Keyder'in de $(2013,186)$ ifade ettiği gibi en cazip reklam, maddi olanaklar ile toplumun geri kalanından yalıtılmış mekânlarda yaşanabilecek bir hayat tarzıdır. Öyle ki bu mekanlar, şehrin tüm pisliğinden, kargaşasından, gürültüsünden uzak, güvenli duvarlarla korunmuş bir yaşam tarzı sunmaktalar. Bu çalışma kapsamında incelenen reklam metinlerinde olduğu gibi, ihtiyaçlar ve ihtiyaçların giderilme şekli toplumsal farklılaşmayı beraberinde getirmektedir. Sınıflar ve kültürler arasındaki farkların; sosyal ve mekansal sınırlar olarak yerleştiği kentlerde, gerilim, şüphe ve ayrımcılık farklı gruplar arasında daha fazla etki ederek (Caldeira, 1996; Ayata, 2012, 37) uzlaşması mümkün olmayan farklılıkları vurguladıkça, kentsel bütünleşme ümidi giderek azalacaktır.

Reklamlarda dikkat çeken bir diğer ortak özellik ise izleyicide lüks bir yaşam tarzı hayali yaratılırken sıklıkla postmodern tüketim toplumun gösterge ve söylemlerinin kullanılmasıdır. Bunlardan en dikkat çekenleri, reklam metninde Osmanlı ve saray metaforlarının, eğlencenin, estetikleştirilmiş yaşamın, ikiliklerin (yeni-eski, doğu-batı, klasik-modern, doğal-yapay-sanatsal-teknolojik) lüks bir yaşam tarzını destekleyecek şekilde verilmesidir. $\mathrm{Bu}$ şekilde sıradan ve gündelik tüketim malları lüks, egzotizm, güzellik ve cazibeyle ilintilendirilerek ve malların işlevsel kullanım değerleri göz ardı edilerek sunulmaktadır (Featherstone, 2005, 144).

Reklamlardaki son ortak özellik ise reklam metinlerinde kişi kullanılmamış olmasıdır. Tüm reklamlarda yalnızca dekorasyona ilişkin unsurlar görülmektedir. Bu yolla kişi kullanılmayan reklamlarda izleyicinin oraya gidip mekanı doldurması amaçlanmaktadır. Bir diğer ifade ile kişi kullanılmayan reklamlarda baş aktör orada bulunmayan izleyicilerdir. Böylece izleyicilerin reklamdaki ürünleri adeta deneyimlemesiyle tüketim süreci başlayacaktır.

Sonuç olarak postmodern, geç kapitalist ya da tüketici toplum olarak ifade edilen günümüzde, ürünlerin sembolik değerleri ile kimlik edinmeye çalışan tüketici bir kitle yaratılmış ve mevcut sistem tarafından yaratılan tüketim kültürü adeta bir baskı aracı haline dönüşmüştür. Bu kimliklerin ve kimliklerin uzantısı olan yaşam tarzlarının oluşumunda ise reklamlar başat aracılardır. Araştırma kapsamında ele alınan reklamlarda da görüldüğü üzere doğayla iç içe lüks konutlar ve bu lüks konutları tamamlayan dekorasyonların, postmodernizme ait nitelikler aracıllğıyla sunumuyla zenginlik ve lüks yaşam tarzları yeniden üretilmekte ve insanlar sunulan bu lüks yaşam 
tarzlarına öykündürülmektedirler. Ayrıca insanların lüks yaşama öykündürüldüğünün bizatihi göstergelerinden biri de çalı̧̧manın örneklemini de oluşturan dekorasyon dergileridir. Bundan sonra gerçekleştirilecek çalışmalarda, lüks yaşam tarzı çerçevesinde farklı dekorasyon dergilerindeki reklamların ya da farklı kategorilerdeki dergi reklamlarının karşılaştırmalı olarak analiz edilmesi önerilebilir.

\section{KAYNAKLAR}

AKÇALI İÇiN, Selda ve YÜCEBAŞ, Mesut (2013). "Reklamlarda Bilim İmgesi", CBÜ Sosyal Bilimler Dergisi, Cilt:11, Sayı:1: 359- 374.

AYATA, Sencer (2012)."Yeni Orta Sınıf ve Uydu Kent Yaşamı”, Kültür Fragmanları, Kandiyoti Deniz ve Saktanber Ayşe (ed), İstanbul: Metis Yayınları, 37-56.

AYDOĞAN, Filiz (2009). Tüketim Kültürünün Gölgesinde Kentler. Marmara Üniversitesi İ.İ.B.F. Dergisi. Cilt 27, Sayı 2: 203-215.

BALİ, N. Rıfat (2007). Tarzı-1 Hayattan Life Style'a. İstanbul: İletişim Yayınları.

BARTHES, Roland (2014). Göstergebilimsel Serüven. Mehmet Rıfat ve Sema Rıfat(çev.). İstanbul: Yapı Kredi Yayınları.

BAUDRILLARD, Jean (2010).Tüketim Toplumu. Hazal Deliceçaylı ve Ferda Keskin (çev.). İstanbul: Ayrıntı Yayınları.

BAUMAN, Zygmunt (1997). Postmodernizm ve Hoşnutsuzlukları İsmail Türkmen (çev.). İstanbul: Ayrıntı Yayınları.

BECER, Emre (1999). İletişim ve Grafik Tasarım. Ankara: Dost Yayınevi. 
BOCOCK, Robert (2014). Tüketim. İrem Kutluk (çev.). Ankara: Dost Kitabevi.

BOURDIEU, Pierre (1984). Distinction: A Social Critique of Judgement of Taste. New York: Routledge \& Kegan Paul.

BURTON, Graeme (2010).Görünenden Fazlası. Nefin Dinç (çev.). İstanbul: Alan Yayıncılık.

CALDEIRA, P. R. Teresa (1996). Building up Walls: The New Pattern of Spatial Segregation in Sao Paulo, International Social Science Journal, 147, Mart akt; AYATA Sencer (2012)."Yeni Orta Sinıf ve Uydu Kent Yaşamı”, Kültür Fragmanları, Kandiyoti Deniz ve Saktanber Ayşe (ed), İstanbul: Metis Yayınları, 37-56.

DAĞTAŞ Erdal ve DAĞTAŞ Banu (2009). "Tüketim Kültürü, Yaşam Tarzları, Boş Zamanlar ve Medya üzerine Bir Literatür Taraması”. Medya Tüketim Kültürü ve Yaşam Tarzları. 27-75. DAĞTAŞ Erdal ve DAĞTAŞ Banu (ed.). Ankara: Ütopya Yayınevi.

DAĞTAŞ, Banu (2003). Reklamı Okumak. Ankara: Ütopya Yayınevi.

DAĞTAŞ, Banu (2009). Reklam Kütür Toplum. Ankara: Ütopya Yayınevi.

ELDEN, Müge, KARPAT AKTUĞLU, Iş1l ve OKAT ÖZDEM, Özen (2014)."Postmodern Dünyada Geleneğin Yeniden İnşası: Osmanlı Kültürel Öğelerinin Reklamlarda Kullanımı", Uluslararası Sosyal Araştırmalar Dergisi, Cilt 7, Sayı 33: 816-827.

FEATHERSTONE, Mike (2005). Postmodernizm ve Tüketim Kültürü. Mehmet Küçük (çev.). İstanbul: Ayrnntı Yayınları.

GALBRAITH, Kenneth John (2009). Büyük Kriz 1929. Elif Nihan Akbaş (çev.) İstanbul: Pegasus Yayınları.

GOTTDIENER, Mark (2005). Postmodern Göstergeler Maddi Kültür ve Postmodern Yaşam Biçimleri. Ankara: İmge Kitabevi.

HARVEY, David (2010). Postmodernliğin Durumu, İstanbul: Metis Yayıncılık.

HIRSCHMAN, Elizabeth C. ve HOLBROOK, Morris B. (1982). "Hedonic Consumption: Emerging Concepts, Methods and Propositions", Journal Of Marketing, Vol.46: 92-101.

IŞIK Nihat, DUMAN Erhan (2012), Reel ve Finansal Göstergeler Açısından 1929 Ekonomik Buhranı ve 2008 Küresel Krizi: Karşılaştırmalı Bir Analiz, Yönetim ve Ekonomi, Cilt 19, Sayı 2: 239-260.

İNCEOĞLU, Yasemin ve ÇOMAK, Nebahat (2009). Metin Çözümlemeleri. İstanbul: Ayrıntı Yayınları.

KEYDER, Çağlar (2013). İstanbul Yerel İle Küresel Arasında. İstanbul: Metis Yayınları.

KORKMAZ, Nilüfer (2009). "Türkiye'de Tüketim Kültürü ve Mekansal Ayrışma”. Medya Tüketim Kültürü ve Yaşam Tarzları. 142-164, DAĞTAŞ Erdal ve DAĞTAŞ Banu (ed.). Ankara: Ütopya Yayınevi.

ODABAŞI, Yavuz (2006). Postmodern Pazarlama. İstanbul: Kapital Medya.

ÖZBEK, Yılmaz (2005). Postmodernizm ve Alımlama Estetiği, Konya: Çizgi Yayınları.

RIFAT, Mehmet (2005). XX. Yüzyılda Dilbilim ve Göstergebilim Kuralları. İstanbul: YKY.

VEBLEN, Thorstein (2014). Aylak Sınıfin Teorisi. Enver Günsel (çev.). Ankara:Tutku Yayınevi.

WILLIAMS, Judith (2001). Reklamların Dili Reklamda Anlam ve İdeoloji. Ahmet Fethi (çev.). Ankara: Ütopya Yayınevi.

YENGIN, Hülya, "İletişimde Renklerin Anlamı", İstanbul Üniversitesi İletişim Fakültesi Dergisi, Sayı 5: 197-205. YOLCU Ergün (2002), "Renklerin Öznel Kullanımı ve Ekinsel Olarak Algılanması", İstanbul Üniversitesi İletişim Fakültesi Dergisi, Sayı:13: 647-660.

YÜCEBAŞ, Mesut (2013). "Orta Sınıflar ve Modern Gettolarda Ayrıcalıklı Yaşam", İnsan Bilim Dergisi. Sayı 21: 21-38. 
Saral Güneş, S., Kükrer Aydın, Ö. / Journal of Yasar University, 2016, 11/43, 220-239

YÜCEL, Halime (2013). İmgeden Yoruma. İstanbul: Ayrıntı Yayınları.

YÜCEL, Tahsin (2006). Göstergeler. İstanbul: Can Yayınları.

ZILLMAN, Dolf (2000). "The Coming of Media Entertainment". Media Entertainment: The Psychology of its Appeal. D. Zillmann \& P.Vorderer, Mahwah (ed.). New Jersey: Lawrence Erlbaum Associates. 